\title{
FLT3/KIT Kinase Inhibitor AKN-028
}

National Cancer Institute

\section{Source}

National Cancer Institute. FLT3/KIT Kinase Inhibitor AKN-028. NCI Thesaurus. Code C101520.

An orally bioavailable protein tyrosine kinase inhibitor for FMS-related tyrosine kinase 3 (FLT3; ST K1) and stem cell factor receptor (SCFR; KIT), with potential antineoplastic activity. FLT3/KIT kinase inhibitor AKN-028 binds to and inhibits both the wild-type and mutated forms of FLT3 and SCFR. This may result in an inhibition of tumor cell proliferation in cancer cell types that overexpress these receptor tyrosine kinases. 